for Medical Research or elsewhere on a variety of subjects, of which the control of cross-infection in hospitals, the birth-rate, population trends, air-borne infection, the remarkable work on scrub-typhus and research on burns and scalds and applied psychology are a few examples. The report, in fact, amounts to a guide to the major trends of medical research in Britain at the present day.

The three main objectives of all this work have been : (1) the maintenance of the health of the Armed Forces and the civilian population, with special regard for malnutrition and the prevention of infectious diseases; (2) the restoration of the wounded and sick to full health; and (3) the creation of conditions which will ensure the highest possible efficiency, safety and comfort of fighting personnel and industrial workers in time of war.

The effort to attain the first of these objectives was very successful. Epidemic infective disease has always been a military menace, but during the Second World War it was reduced to military insig. nificance. In civil life it was also checked, although the common cold, influenza and a variety of industrial hazards remain and are recognized as urgent problems which are now being energetically investigated. The value of the nutritional work done during the War is so well recognized that it needs no comment here.

The success of the attack on the second objective is probably not fully appreciated outside the medical profession. Powerfully aided by the discovery of the sulphonamide drugs and the effects of penicillin, and by remarkable advances in surgical treatment, the work done in this field saved the lives and returned to useful occupation many men and women who formerly would have either died or would have survived only in helplessness and misery.

The story of the attack on the third objective is in some respects the most interesting part of the report. It includes accounts of the work on the physiology of flight at high altitudes and of deep-sea diving; the design of clothing for airmen and for life in arctic and tropical climates; the human problems associated with submarines and surface ships; the design of aircraft, guns and armoured vehicles in relation to the abilities and needs of the men who use them; and the special problems, physiological and psychological, arising from the use of complicated panels of instruments, engine controls and similar devices inseparable from modern mechanized warfare and industry.

As the report says, the main factor limiting the efficiency of a machine or weapon may be the human being using it, so that machines and weapons should not be designed by physicists and engineers without the co-operation of the psychologist, the physiologist and the medical man. To industry the same considerations apply. Lighting, heating, ventilation, noise, dust, toxic products of the factory-all these, as well as the relations between the machine and the people who use them, need scientific study if the best economic, social and humane results are to be attained.

During the period covered by the report the Medical Research Council has unhappily lost by death or retiroment the services of men whose experience and creative ability were very valuable. The deaths of Sir Patrick Laidlaw and Sir Thomas Lewis, to whose influence and achievement the report pays tributes, were grievous blows. Although Sir Henry Dale retired after twenty-eight years of active service, he remained on the Council for four years longer, and his wide experience and outstanding ability are still happily available in consultation. Sir Edward Mellanby, secretary of the Medical Research Council, is fortunately still in office. $\mathrm{He}$ must be well satisfied with this record of the work to which he has devoted so much wise counsel and prolonged hard work.

G. LAPAgE

\section{COUNCIL FOR SCIENTIFIC AND INDUSTRIAL RESEARCH, AUSTRALIA}

\section{ANNUAL REPORT}

$T$ HE twentieth annual report of the Council for Scientific and Industrial Research, Common. wealth of Australia, covering the year ended June 30, 1946 (Canberra : Gov. Printer. 5s. 4d.), now available, refers to the decision to establish a Division of Textile Research as a result of the visits of Mr. B. $\mathbf{H}$. Wilsdon, Prof. J. B. Speakman, Dr. F. T. Peirce and Dr. A. C. Goodings mentioned in an earlier report; negotiations are in hand for the acquisition of a site for the headquarters laboratory at Geelong. Some work in the wool textile field will be undertaken by existing divisions.

The Building Materials Research Section and the Flax Research Laboratory came into existence dur. ing the year, and experimental work in nuclear physics and metallurgy was initiated in collaboration with the University of Melbourne. The Council has resumed its earlier practice of sending members of its scientific staff overseas to collect information on new developments and to acquire general experience in research and training in new techniques. A series of studentships is also to be offered each year to enable recent graduates of Australian universities to gain general research experience and training overseas in subjects related to the Council's programme of research, and then to return to Australia as members of the Council's staff. The Council's scientific liaison offices in London and Washington are now being maintained on a restricted basis to serve the peace-time needs of the Council.

With the end of the War, the Division of Plant Industry is devoting much more time to a study of pasture and weed problems, and the joint State and Council Weeds Co-ordination Committees are being revived. The North Australian Development Committee established by the Commonwealth Government and those of Queensland and Western Australia initiated a rapid examination, in the KatherineDarwin-coast area, of the vegetation in relation to geology, soils and climate, the distribution, grazing and quality of stock, etc., during the 1946 dry season. Another committee on which the Council is represented, with the Waite Agricultural Research Institute and the Departments of Agriculture of South Australia and Tasmania, has been established to supervise investigations of dieback or 'gummosis' of apricots. Pasture investigations have included the management of Phalaris - subterranean clover and of Wimmera rye grass-subterranean clover in sown pastures, and a large-scale grazing trial of natural pasture in co-operation with the New South Wales Department of Agriculture. Mineral deficiency, pasture establishment under cover crops, various studies of mixtures of lucerne and Paspalum sero- 
biculatum, and studies of cattle pasture and native legumes are also reported. Weed investigations have ranged over the control of galvanized burr, mintweed, capeweed in flax crops and studies of the action of plant poisons. Facilities for plant testing were re-organised and developed, some 510 species and varieties being received from abroad for trial during the year, while more than a thousand samples of seeds of Australian native and crop plants were sent to overseas agricultural and botanical institutions. Trials of introduced linseed varieties gave particularly promising yields, and linseed is believed to have good prospects as a commercial crop in southern Queensland. Experiments with the guayule rubber plant continued, and plants grown at Lawes under natural rainfall compared favourably in yield and rubber content with the best irrigated plantings in South Australia. Wheat investigations covered take-all disease. The study of fruit storage problems was again taken up, and work on the vitamin $\mathbf{C}$ content of tomato varieties continued. Trials with dichloroethylene and dichloroethane gave good results in the control of woolly aphis in propagating beds, and aspects of the dieback disease of apricot have been surveyed. Drug plant investigations have been concentrated on the study of Duboisia spp. as sources of hyoscine and atropine; the study of varieties of Papaver somniferum as sources of opium alkaloids; and the systematic search for sources of pharmaco. logical and insecticidal substances in native plants. Vegetable investigations have included genetical work aimed at producing hybrids resistant to the potato viruses $A, X, Y$ and leaf roll; agronomic studies of selected varieties of tomatoes; peas and beans; the use of zinc oxide as a disinfectant on cut potato setts ; and spotted wilt of tomato.

Reports from the Divisions of Economic Entomology and of Animal Health and Production both give some prominence to trials with D.D.T. and 'Gammexane'. A preparation of the former, known as 'Rucide' and containing 50 per cent of the $p p$-isomer, which forms a stable fine emulsion when melted and poured into water, has given very promising results against cattle tick, in control of buffalo fly on dairy cattle and beef cattle, oriental peach moth, potato moth and cabbage moth and butterfly. D.D.T. has also given promising results in control of sheep blowfly. Other work by the Division of Economic Entomology has been concerned with the biological and clinical determination of D.D.T. and other insecticides, the biological control of cabbage white butterfly, citrus red scale, brown olive scale and potato moth, the insect control of St. John's wort, and insect vectors of plant viruses. The Division's work on wheat-storage problems terminated during the year; but promising results were obtained both with D.D.T. and ' 666 ' against hoppers and adults of the Australian plague locust. In the Division of Animal Health and Production, systematic epidemio. logical studies of mastitis were continued on the experimental herds of dairy cattle, and the good results obtained with penicillin in bacterial infections of the udder have been confirmed. Other investigations have covered toxæmic jaundice in sheep, contagious abortion of cattle and the toxicity of wheat for stock, while at the McMaster Animal Laboratory studies have been made of anthelmintics against Hoemonchus contortus, Trichostrongylus spp.

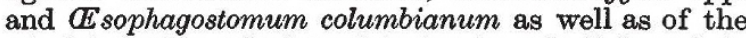
administration of phenothiazine in salt lick and in small repeated doses, the effect of worm parasites on body weight and wool growth, external parasites of sheep and the blowfly strike problem. Biochemical studies have included the mineral metabolism of sheep and poisonous plants; studies in wool biology have included specifications of sheep types for wool production and histological studies of the sheep's skin. At the F. D. McMaster Field Station, studies have been made of the inheritance of skin wrinkles in sheep and of various faults and specific breeding groups. An investigation has been commenced into beef production in Australia, and an officer has been appointed for poultry breeding investigations.

The study of the nutritional physiology of ruminants has again been undertaken, particularly with the view of extending knowledge of the chemical, microbiological and physiological mechanisms involved in rumination and in the production of wool fleece, and the detailed study of the influence of protein intake on the latter has already indicated several broad principles. Other studies in the biochemical field have covered chronic fluorosis, the influence of deficiencies of minor elements, cobalt and copper deficiency and the effect of copper and cobalt dressings on grazing sheep. Soils investigations have been concerned mainly with problems in land settlement; surveys of various types have proceeded in five States. Considerable attention has been given to the place of soil investigations in research on building problems with particular reference to foundations, but lack of qualified research staff has hampered development. Irrigation settlement investigations at Merbein, Victoria, and Griffith, New South Wales, have proceeded on the usual lines, covering irrigation and drainage problems, soil moisture problems of irrigated lands, soil deterioration from irrigation, viticulture, fruit processing and vegetable agronomy.

In the field of forest products there has been a rapid transition from war-time problems to research on peace-time problems, and heavy demands from industry for assistance, particularly in connexion with housing, have been received when the Division concerned was short of staff through transfers. A feature of the year was the first Forest Products Conference, to which representatives from all the State forest services and from the Commonwealth Forestry and Timber Bureau and the Forest Department of the New Guinea and Papua Administration were invited. A major purpose of the Conference was to discuss programmes of work of the Division, the Division of Wood Technology of the New South Wales Forestry Commission and the Queensland Sub-Department of Forestry. Co-operation with the pulp and paper industry in the field of wood chemistry continued, and further work was carried out on lignin and pulp evaluation. The Timber Physics Section continued its work on wood-water relations and the physical properties of wood, while the Timber Mechanics Section, in addition to testing work, also made fundamental studies of the properties of wood, longtime loading and the strength and deflexion of floors. Work was also carried out in the Division on the development of building materials from wood products and other organic substances and on timber preservation, marine borer attack, fundamental factors affecting the penetration of preservatives under pressure, the diffusion of soluble preservatives into green timber, veneer and glueing, and the development and testing of adhesives.

Important changes have been made in food preservation investigations. All short-term investi- 
gations to maintain or increase the output of canned foods have been terminated to permit concentration on such long-term projects as the effects of maturity and variety on the quality of certain processed fruits and vegetables. Investigations on the storage of egg powder have been terminated, and work on the processing and storage of dehydrated vegetables curtailed; while studies on preventive measures for bacterial rotting in shell eggs have been resumed, as have some fundamental studies on the metabolism of fruit in cold storage and on problems of heat transfer and evaporation in cooling meat in refrigeration chambers. Other investigations have dealt with the organisation of the plant cell and its relation to cell stability and the respiration of the plant cell, particularly the organic acid metabolism and the nature of the oxidative enzymes, skin coatings for apples, the effectiveness of 'Pliofilm' wraps, 'stretch wraps' and case liners compared with a standard wax treatment for storing oranges. Features of the year's work on canning and fruit products were modified procedures for canned citrus juices, the canning of Freestone peaches, the steam-flow, hot-lid method of obtaining vacuum in commercial automatic canclosing machines and the maintenance of colour by addition of soluble tin to fruit packed in lacquered cans.

The exceptionally interesting report from the Fisheries Division refers to the return of the Division's research vessel from the Royal Australian Navy and the gradual resumption of research activities. The routine testing of the new southern trawling grounds with the Danish-seine net continued, and biological investigations covered Clupeoid fish, whitebait and Tuna species, salmon and mullet. Hydrological and seaweed investigations are also recorded, including both the production of agar and the use of seaweed as fodder ; many aerial observations of pelagic fish were made from aireraft allotted by the Royal Australian Air Force.

The work of the Division of Electrotechnology has been devoted almost entirely to the establishment of the facilities required for the maintenance of standards and for measurements, and release of the staff of the Physics Division from routine testing has permitted further attention to research. Fundamental investigations on the physics of wool fibres, particularly in relation to their frictional properties, have been continued and extended to include studies of the ultimate structure of the fibres. Further work has been done with the view of maintaining the International Temperature Scale quite independent of secondary standards calibrated elsewhere, and an instrument has been developed for measuring the temperatures of estuarine muds and waters. Some work on solar physics has been commenced, and the nucleus of a section to work on the physics of solids has been established.

The Division of Aeronautics is now concentrating on more fundamental and long-range problems, turbine engine research being particularly prominent. The instability characteristics of flat and curved plates of both isotropic and orthotropic material have been investigated, and work on plywood plates subjected to end compression has been carried further. Preliminary work has been undertaken on tungsten-chromium alloys, and tests on the corrosion of the alloys of mock-up cooling systems by inhibited and uninhibited ethylene glycol has been continued with a coolant containing sulphonated gyro-oil as inhibitor. A study has been made of the mechanism of corrosion and film formation in aluminium and its alloys. In the Division of Industrial Chemistry the process devised for the preparation of chrome chemicals from chromite by an acid treatment reached an advanced stage in pilot plant, and pilot plant tests have also been undertaken on the chemical isolation of cerium, thorium and lanthanum com. pounds from monazite. A survey is being made of Australian ceramic materials, and the Physical Chemistry Section has continued its work on surface chemistry with particular reference to aspects affecting the flotation process for the separation of minerals. Corrosion in aircraft engine cooling systems and condenser tubes in power generating plant, the adsorption of surface-active agents from organic solvents, sugar-cane wax, the pilot-scale isolation of mannitol from the exudate of sugarwood, catalytic oxidation of ethylene to ethylene oxide and catalytic dehydration of 2:3-butylene glycol to butadiene, the loosening of wool from skins by sweating and with depilatories are among other problems which received attention during the year.

In returning to the study of fundamental problems, the Division of Radiophysics has placed emphasis on researches into the propagation of radio waves, atmospheric physics and vacuum physics. The Lubricants and Bearings Section, renamed the Tribophysics Section, has been concerned with the mechanism of boundary lubrication, surface damage and wear, silicones, surface-active compounds and mechanical properties, the deformation of metals by heating and cooling, deformation and recrystallization of duplex alloys and the electrolytic polishing of metals.

\section{OBITUARIES}

\section{Sir George Newman, G.B.E., K.C.B.}

George Newman was born at Leominster, Herefordshire, on October 23, 1870. He was the second son of Mary Anna Pumphrey and Henry Stanley Newman, who for twenty years edited the Quaker weekly, the Friend. Sir George was educated at Bootham School, York, and the University of Edinburgh. He graduated M.B., C.M. in 1892 and proceeded to the M.D. in 1895, his thesis on leprosy qualifying for the gold medal. In the same year he obtained the Cambridge D.P.H. During 1896-1900 he was senior demonstrator in bacteriology and lec. turer in infectious diseases at King's College, London, of which he was later to become a fellow. During 1900-7 he was medical officer of health of the County of Bedfordshire and of the Metropolitan Borough of Finsbury; and lectured on public health at St. Bartholomew's Hospital. He early acquired reputation as an energetic administrator, and published works on the bacteriology of milk, on the relation of bacteriology to public health and on infant mortality.

In 1907, Newman was appointed the first 'chief medical officer' of the Board of Education. With Sir Robert Morant, the permanent secretary, and his able colleagues, Dr. Eichholz, Dr. Ralph Crowley and Dame Janet Campbell, Newman built up the school medical service and extended its scope and opportunities. As a result, the mental and physical education of the children of Britain has improved beyond all comparison with the past. The years 